\title{
DNA Related Enzymes as Molecular Targets for Antiviral and Antitumor- al Chemotherapy. A Natural Overview of the Current Perspectives
}

\author{
Hugo A. Garro* and Carlos R. Pungitore \\ INTEQUI-CONICET, Fac. Qca., Bioqca. y Fcia., Univ. Nac. de San Luis (U.N.S.L), Chacabuco y Pedernera, 5700 San \\ Luis, Argentina
}

A R T I C L E H I S T O R Y

Received: February 05, 2018

Revised: April 17, 2018

Accepted: April 19, 2018

DOI

$10.2174 / 1389450119666180426103558$

\begin{abstract}
Background: The discovery of new chemotherapeutic agents still remains a continuous goal to achieve. DNA polymerases and topoisomerases act in nucleic acids metabolism modulating different processes like replication, mitosis, damage repair, DNA topology and transcription. It has been widely documented that Polymerases serve as molecular targets for antiviral and antitumoral chemotherapy. Furthermore, telomerase is a ribonucleoprotein with exacerbated activity in most of the tumor cell lines, becoming as an emergent target in Cancer treatment.
\end{abstract}

Methods: We undertook an exhaustive search of bibliographic databases for peer-reviewed research literature related to the last decade. The characteristics of screened bibliography describe structure activity relationships and show the principal moieties involved. This work tries to summarize the investigation about natural and semi-synthetic products with natural origin with the faculty to inhibit key enzymes that play a crucial role in DNA metabolism.

Results: Eighty-five data references were included in this review, showing natural products widely distributed throughout the plant kingdom and their bioactive properties such as tumor growing inhibitory effects, and anti-AIDS activity.

Conclusion: The findings of this review confirm the importance to find new drugs and biologically active natural products, and their potential medicinally useful benefits.

Keywords: DNA polymerases, telomerases, topoisomerases, inhibition, molecular target, chemotherapy.

\section{INTRODUCTION}

Natural products and their derivatives have been used for a long time in traditional medicine. In addition to their low cost and wide practice, natural products and their derivatives attract growing interests and are valuable resources for drug design and pharmaceutical development. Plants have a long history of use in the treatment of cancer. Scientists have identified many molecules with anticancer activities from nature, including taxol, vinblastine, camptothecin, paclitaxel, cephalotaxine, matrine, and colchicine [1-4].

Chemotherapy remains to be the standard treatment for initial or advanced stages of cancer. However, commonly used chemotherapeutic agents may induce damage in healthy cells or tissues. Thus, in recent years, there has been an increased effort in the development of new, efficient anticancer drugs exhibiting low toxicity, that are not affected by mechanisms of chemo-resistance [5-7].

Complexity and molecular diversity, high selectivity and specific biological activities are characteristics of natural

*Address correspondence to this author at the INTEQUI-CONICET, Fac. Qca., Bioqca. y Fcia., Univ. Nac. de San Luis (U.N.S.L), Chacabuco y Pedernera, 5700 San Luis, Argentina; Tel: +54 (0266) 4520300;

E-mail: hugocanaya@yahoo.com.ar products, and many of these metabolites have some receptorbinding activity in a specific manner [8]. Consequently, some proteins can become true molecular targets and then develop certain pharmacological action. One kind of targets could be DNA-related enzymes. These receptors play a crucial role in DNA metabolism, including processes such as recombination, replication, transcription and chromosome segregation during cell division. The inhibition of these allow the development of new leads, like antitumoral and antiviral agents. Considering the enormous complexity and structural diversity of natural products, we can find alkaloids, chalcones and flavonoids, iridoids, polyalcohols, lipids and terpenoids, macrocycles, quinones, and polyphenols capable of showing this activity, but with the accuracy of maintaining a defined configuration of its chiral centers. This work tries to summarize the investigation about some remarkable natural and semi-synthetic products that share a natural origin, with the ability to inhibit key DNA-related enzymes $[9,10]$.

\section{DNA POLYMERASES}

DNA polymerases are ubiquitous enzymes with the ability to create new polymers of deoxyribonucleic acid from four different kinds of subtracts, known as nitrogenous DNA bases. These proteins, together with different topoisomerases 
and helicases, play a crucial role in DNA metabolism, such as recombination, replication, transcription, and chromosome segregation during meiosis and mitosis. Hyperproliferative diseases such as cancer, autoimmune conditions, and vi$\mathrm{ral} / \mathrm{bacterial}$ infections are associated with uncontrollable DNA replication. For this reason, it has long been accepted that these enzymes are important molecular targets for the development of cancer and antiviral chemotherapeutic agents [11-17].

In the subsequent paragraphs, some natural products and derivatives with DNA polymerase inhibitory activity are categorized according to their chemical structures.

\subsection{Flavonoids and Chalcones}

The flavonoid group comprises a large family of plantderived polyphenolic compounds of medium to low molecular weight, which exhibit diverse biological activities. The naturally occurring chalcones, or benzopyrone derivatives, and the phenylchromones are widely distributed throughout the plant kingdom as components in fruits, vegetables, tea, bark, roots, flowers, grains, etc. [18, 19].

Myristinin is a bioflavonoid isolated from Myristica cinnamomea [20]. This occurs as different stereoisomers known as myristinin A and myristinin B/C. In 2004, Maloney and co-authors prepared (+)-myristinin stereoselectively with absolute stereochemistry. In addition to DNA-damaging ability, (+)-myristinin was also shown to inhibit DNA polymerase $\beta\left(\mathrm{IC}_{50}=2.8 \mu \mathrm{M}\right)$, a DNA-repairing enzyme (Fig. 1) [21].<smiles>CC(C)(C)C(=O)c1c(O)cc(O)c([C@@H]2C[C@H](c3ccc(O)cc3)Oc3cc(O)ccc32)c1O</smiles>

Fig. (1). Chemical structure of (+)-myristin.

Another kind of non-glycosylated flavonoids able to inhibit DNA polymerase $\beta$ was 5-methoxyflavone. The threeringed molecular scaffold of this flavone is easy to synthesize in the development of nature-inspired compounds (Fig. 2) $[22]$.<smiles>COc1cccc2c1C(=O)CC(c1ccccc1)O2</smiles>

Fig. (2). Chemical structure of 5-methoxyflavone.

Drugs with low molecular weight have usually shown a good ability to cross cell membranes by passive diffusion, such as the nuclear membrane. Furthermore, simple alkylat- ed flavonoids have shown selective pharmacological properties, such as xanthohumol. This prenylated chalcone exhibited remarkable inhibitory activities against human DNA polymerase $\alpha$ (Fig. 3) [23].<smiles>COc1cc(O)c(CC=C(C)C)c(O)c1C(=O)/C=C/c1ccc(O)cc1</smiles>

Fig. (3). Chemical structure of xanthohumol.

It should be noted that the use of more complex structures increases the probability of improving the physicalchemical interactions between molecules and receptors. In this case, biflavonoids from Dacrydium balansae have shown a potent inhibition of the Dengue virus NS5 RNAdependent RNA polymerase (Fig. 4) [24].<smiles>O=c1cc(-c2ccc(Oc3c(O)cc4occ(-c5ccc(O)cc5)c(=O)c4c3O)cc2)oc2cc(O)cc(O)c12</smiles>

Fig. (4). Chemical scaffold of a kind of active biflavonoid.

Although the receptor used is not specifically a DNAdependent polymerase, it would be interesting to conduct a study on this kind of enzyme using flavonoid dimers. The use of duplicate molecular scaffolds, in addition to favoring greater structural complexity, generally leads to a better cellular permeability through passive diffusion mechanisms, which results from a greater hydrophobicity [25].

\subsection{Lipids and Terpenoids}

Lipids represent a class of metabolites with interesting values of cLogP mainly due to their hydrocarbon constitution. These can be made as different forms: from molecules with very low molecular weight to complex structures with more than 100 carbon atoms like dolichol. Terpenes are secondary metabolites derived from a unit of five-carbon atoms called isoprene, thus sharing different building blocks of this [26-29].

The first attempts to discover $\beta$-polymerase inhibitors conducted by Mizushina et al. revealed that long chain fatty acids suppressed polymerase activity [30]. They also found that terpeno-benzoic acids, from the plant Myrsine seguinii, showed an inhibitory effect against enzymes involved in DNA synthesis, such as calf DNA polymerase $\alpha$ (pol. $\alpha$ ), rat DNA polymerase $\beta$ (pol. $\beta$ ) and one of the $\beta$ family polymerases, calf thymus terminal deoxynucleotidyl transferase (TdT). Its $\mathrm{IC}_{50}$ values were $22 \mu \mathrm{M}$ for pol. $\alpha, 11 \mu \mathrm{M}$ for pol. $\beta$, and $46 \mu \mathrm{M}$ for TdT, respectively (Fig. 5) [31]. These authors suggested that the presence of carboxylic acid is an 
important structural factor for the DNA polymerase inhibitory activity.

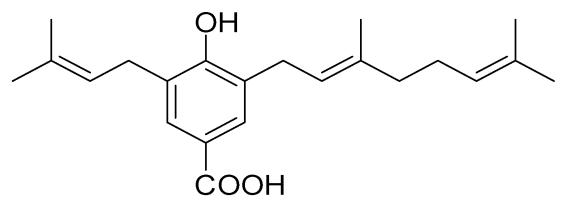

Fig. (5). Chemical structure of a terpeno-benzoic acid from Myrsine seguinii.

Another class of attractive lipid carboxylic acid which has shown this activity is 7,8-euphadien, a type of triterpenoid from Brackenridgea nitida and Bleasdalea bleasdalei. This product inhibited rat DNA polymerase $\alpha$ with an $\mathrm{IC}_{50}$ value of $23 \mu \mathrm{M}$ in the presence of bovine serum albumin (BSA) and 9.7 $\mu \mathrm{M}$ in the absence of BSA (Fig. 6) [32].

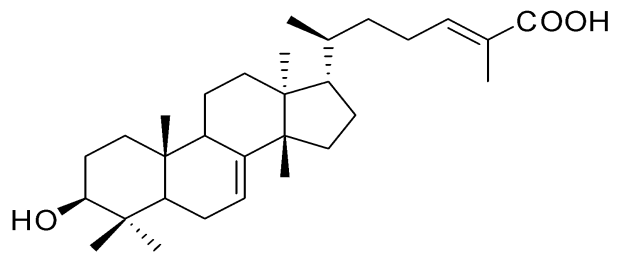

Fig. (6). Chemical structure of 7,8-euphadien.

Furthermore, bioassay-guided fractionation of extracts prepared from Couepia polyandra and Edgeworthia gardneri resulted in the isolation of the DNA polymerase $\beta$ inhibitors, oleanolic acid $\left(\mathrm{IC}_{50}=24.98 \pm 3.3 \mu \mathrm{M}\right)$ and betulinic acid $\left(\mathrm{IC}_{50}=46.25 \pm 3.1 \mu \mathrm{M}\right)$, (Fig. 7) [33].
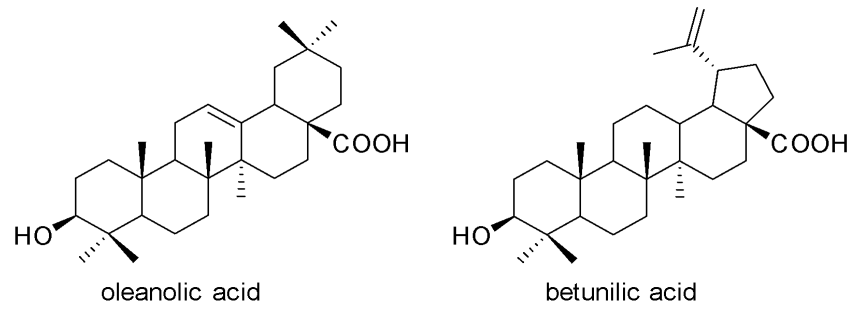

Fig. (7). Chemical structure of oleanolic and betulinic acids.

\subsection{Iridoids and Other Polyalcohols}

Iridoids, glycosides and other polyalcohols display an elevated content of oxygen, giving these molecules high water solubility. Their poor lipophilicity might account for the lack of biological activity against human solid tumor cell lines. This may appear, in principle, to be a disadvantage when crossing lipid membranes; but the presence of hydroxyl groups increases the probability of direct enzyme recognition through hydrogen bonds [34-36].

Iridoids may even emulate the nitrogenous substrates of DNA-related enzymes. The bicyclic aglycone of DNA polymerase inhibitor catalpol could mimic the purine scaffold present in natural nucleosides because they share similar electronic surface distribution (Fig. 8) [37].

In 2010, our research group synthesized a novel catalpol derivative able to inhibit the KlenTaq fragment. By conduct- ing molecular dynamic studies, we proposed a recognition inside the catalytic site by hydrogen bonds between glycosidic hydroxyls and polar chain residues (Fig. 9) [36].

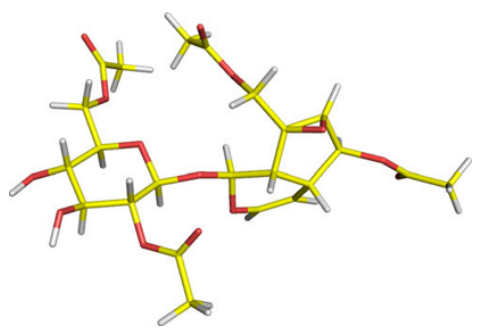

Fig. (8). Conformational structure of a catalpol derivative.

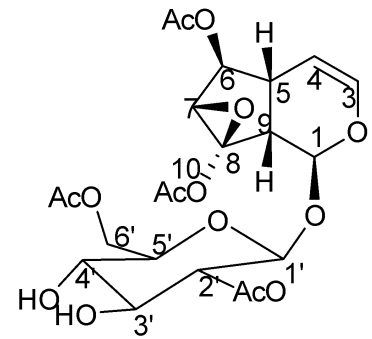

Fig. (9). Chemical structure of $6,10,2^{\prime}, 6^{\prime}$-tetraacetyl- $O$-catalpol.

Furthermore, Pungitore et al. prepared a series of novel lipophilic catalpol analogs by the regioselective addition of silylether moieties. Antimetabolites cannot enter cells easily by passive diffusion due to their low lipophilicity. However, these products did show antitumoral activity, possibly due to their higher cLogP values (Fig. 10) [38].

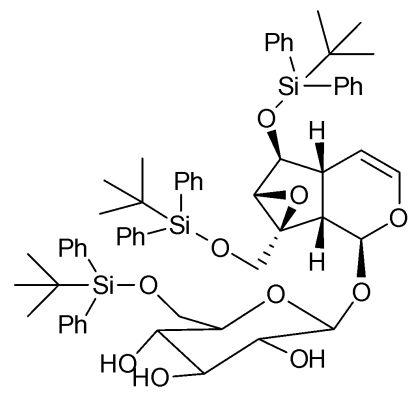

Fig. (10). Chemical structure of a lipophilic catalpol derivative.

Recently, Garro et al. isolated a new epimer iridoid of catalpol from Buddleja cordobensis [39]. This metabolite was even more active than catalpol. Similarly, two silylether derivatives with higher lipophilicity also showed inhibition. Considering a different configuration of carbon six, the activity may improve; and hydrophobic derivatives could act against human solid tumors (Fig. 11).

From Buddleja cordobensis, we also could isolate verbascoside as a per-O-acetyl derivative. This disaccharide has shown to be a potent inhibitor with $\mathrm{IC}_{50}=1.21 \mu \mathrm{M}$, possibly due to its complex structure and the large number of chiral centers (Fig. 12).

Finally, the natural polyalcohol petasiphenol, extracted from the Japanese plant Petasites japonicus, was shown to selectively inhibit pol $\lambda$ activity, but it resulted to be inactive 
towards the structurally-related polymerase $\beta$, as well as towards replicative polymerases (Fig. 13). Petasiphenol inhibited the pol $\lambda$ activity indirectly by acting at the BRCT (Cterminal domain of a breast cancer susceptibility protein), and could not recognize the BRCT domain structure of other proteins, suggesting that the three-dimensional structure of the BRCT domain of pol $\lambda$ differs of pol $\beta$ [40].
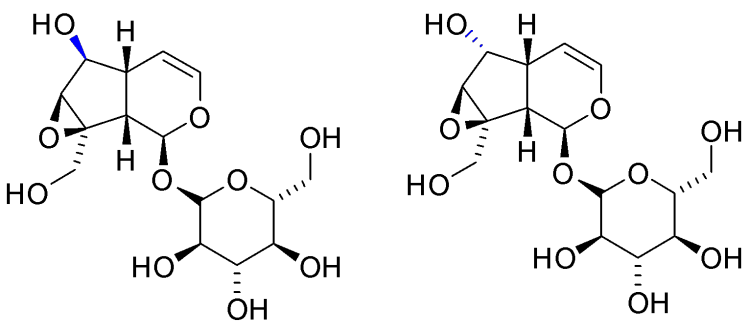

Fig. (11). Chemical structures of catalpol (left) and 6-epi-catalpol (right).

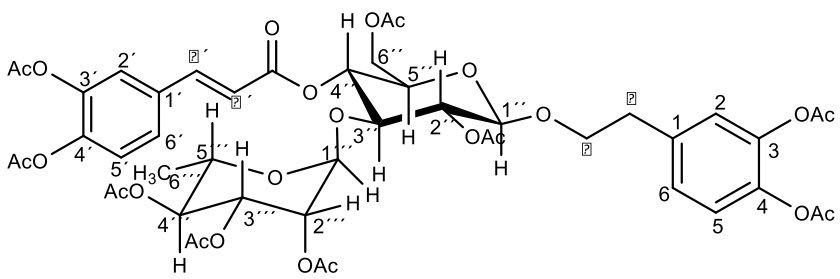

Fig. (12). Chemical structure of per-O-acetyl-verbascoside.<smiles>O=C(COC(=O)C=Cc1ccc(O)c(O)c1)Cc1ccc(O)c(O)c1</smiles>

Fig. (13). Chemical structure of petasiphenol.

\section{TELOMERASE}

Telomeres are repetitive DNA elements at the end of chromosomes that protect against chromosomal erosion and rearrangement inside the nucleus. This unique structural formation of DNA is different from the well-known helical structure that DNA adopts. Furthermore, it has recently been proposed as a molecular target for new kinds of anticancer agents, in particular, molecules able to stabilize the intramolecular G-quadruplex. Telomerase is part of an enzyme complex that counteracts telomeres shortening. This protein is constituted by the catalytic subunit telomerase reverse transcriptase (TERT) and its RNA component sequence [41, 42].

Human telomeres are simple (TTAGGG) $n$ islands of 5$15 \mathrm{~kb}$ repeated sequences located at the ends of chromosomes. This structure capping the chromosome termini prevents aberrant recombination. The mutagenesis events caused by these aberrant changes could eventually result in a malignant cell differentiation. Highly proliferative cells require elevated levels of telomerase activity to offset such loss of telomeric DNA. This enzyme has become an obligatory objective for anti-cancer research, as it promised a unique target for chemotherapy without the related side effects of conventional chemotherapeutics [43,44]. As an anticancer strategy, efforts have been invested in targeting and lowering telomerase activity, which is frequently found to be overexpressed in cancerous cells [45].

\subsection{Alkaloids}

Quinoline compounds are characterized by a doubleringed structure that contains a benzene ring fused to a heterocyclic aromatic nitrogen pyridine. These products have shown strong inhibition with sub-toxic concentrations, such as 11-substituted cryptolepine analogs (Fig. 14).<smiles>CN(C)CCNc1c2ccccc2nc2c1[nH]c1ccccc12</smiles>

Fig. (14). Chemical structure of 11 substituted quindolines.

In 2005, Zhou et al. demonstrated its capacity to stabilize a G-quadruplex, and that an electron-donating substituent at the 11-position can enhance the basicity of the nitrogen atom, thus increasing the electrostatic interaction between the derivatives and the negative electrostatic center of the Gquadruplex [46, 47].

In the last decade, Neidle's and Huang's groups reported that 13 and 9 -substituted berberine derivatives had the ability to selectively bind to G-quadruplex over double-stranded DNA, including those present in the human oncogene c-myc sequence (Fig. 15) [48, 49].

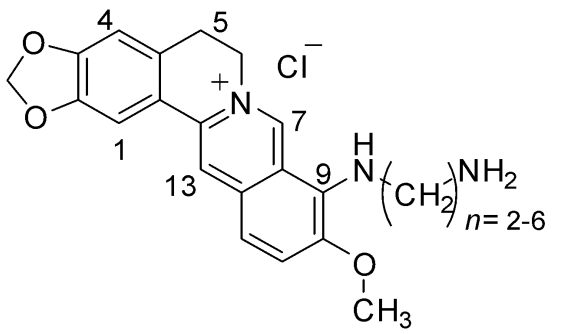

Fig. (15). Chemical structure of 9 substituted berberine analogs.

Overexpression of this oncogene is related to the increase of cellular and malignant proliferation. Guanine rich sequences present in its promoter region controls $80-90 \%$ of the transcription activity of c-myc. Several small molecules, like chelerythrine, which can stabilize this quadruplex structure, are putative agents to downregulate c-myc expression (Fig. 16). Interestingly, the protonated iminium form of chelerythrine is able to intercalate into double stranded DNA [50].

Electrospray ionization mass spectrometry (ESI-MS) and Circular Dichroism (CD) can be used to determine the formation and recognition of human telomere G-quadruplex and selectivity versus duplex DNA. For example, the binding of homobarringtonie, a natural alkaloid with a seven-membered heterocycle, was established using these methods (Fig. 17) [51]. 
<smiles>COc1ccc2c(c1OC)C(O)N(C)c1c-2ccc2cc3c(cc12)OCO3</smiles>

Fig. (16). Chelerythrine forms.

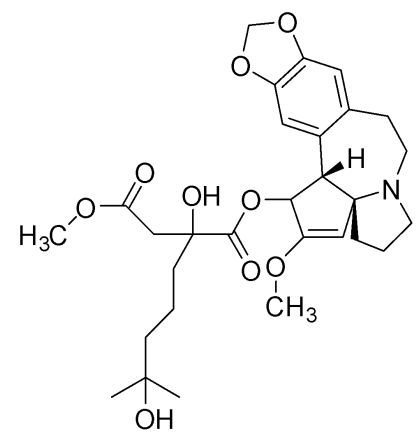

Fig. (17). Chemical structure of homobarringtonie.

\subsection{Porphyrins and Perylene Compounds}

Polycyclic aromatic hydrocarbons (PAHs) are a large group of hydrophobic chemicals, characterized by presenting conjugate systems within a planar geometry [52]. Some porphyrin derivatives bearing $N$-methylpyridinium cationic side arms are able to bind with parallel four-stranded $\left(\mathrm{TG}_{4} \mathrm{~T}\right) 4 \mathrm{G}$ quadruplex DNA in buffers containing $\mathrm{Na}+$ cation (Fig. 18) [53].

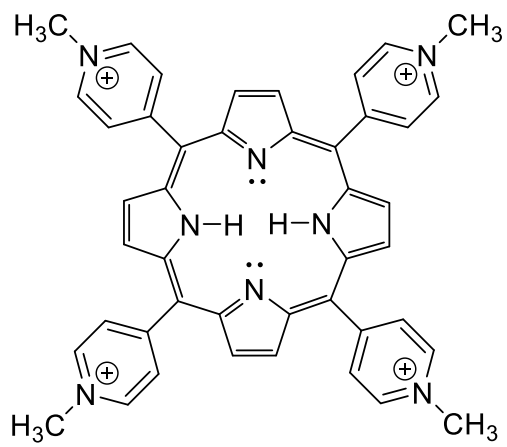

Fig. (18). Chemical structure of porphyrin derivatives bearing $N$ methylpyridinium cations.

Perylenes and coronenes are hydrosoluble PAHs able to recognize and specific binding of telomeric G-quadruplexes. These compounds contain a large planar aromatic system moiety, which can bind to the terminal G-quartet of a Gquadruplex via $\pi-\pi^{*}$ stacking in a threading intercalation mode. For example, Franceschin et al. prepared four "not self-aggregated" perylene derivatives with activities lower than $20 \mu \mathrm{M}$ of telomerase inhibition (Fig. 19).

The most interesting point was the strong inhibition and the water solubility of these, which suggest a potential low toxicity [54]. The same group of researchers also prepared coronene derivatives capable of specifically recognizing secondary structures of G-quadruplex (Fig. 20) [55].

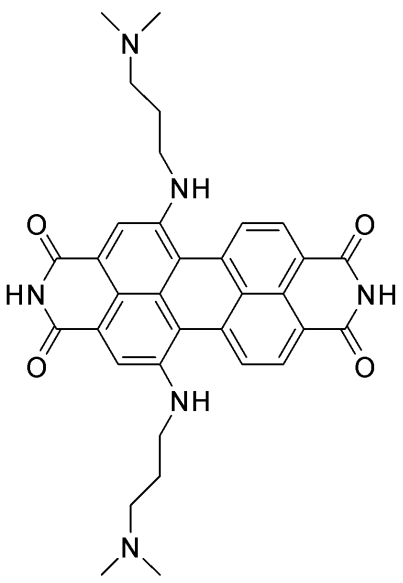

Fig. (19). Chemical structure of a perylene derivative.

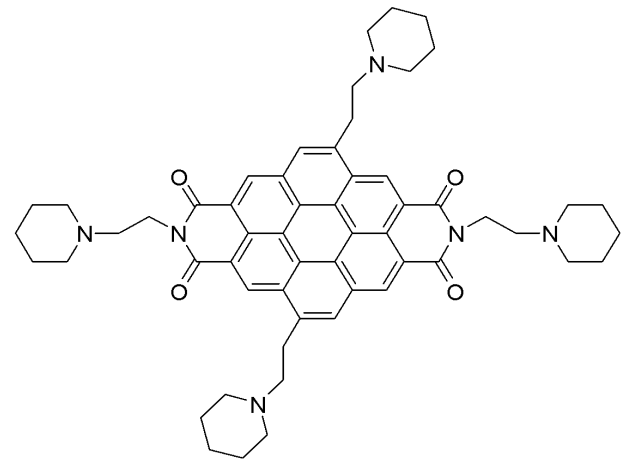

Fig. (20). Chemical structure of a coronene derivative.

\subsection{Quinones}

Quinones containing compounds have been widely used for their antitumour activity. Nature is an important source of novel quinone analogues, such as para and orthobenzoquinones, naphthoquinones and anthraquinones. A1most 350 natural naphthoquinones have been discovered. Now, the co-existence of naphthoquinones and anthraquinones in plants is not atypical, and they have a common precursor. New types include isofuranonaphthaquinones and naphthoquinones linked to coumarin, which form substantial subgroups with interesting activities [56]. For example, celastrol a quinone methide triterpenoid from the Chinese medicinal root bark of Tripterygium wilfordii, possesses beneficial therapeutic properties. A series of celastrol derivatives were prepared as potential telomerase inhibitors, showing a direct correlation between telomerase inhibition and anti-proliferative inhibition of SMMC-7721 in human hepatoma cells. This compound with hydrophilic moieties show potential non-toxic side effects (Fig. 21) [57, 58]. 


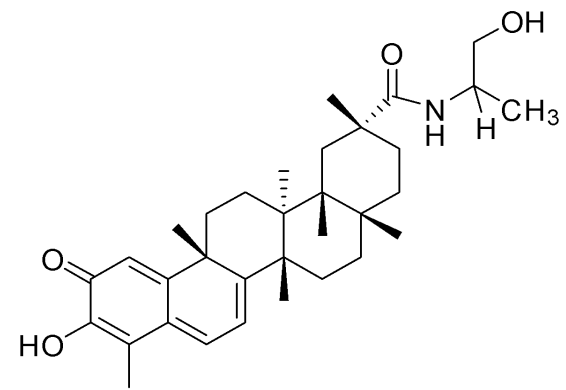

Fig. (21). Chemical structure of a hydrophilic celastrol derivative.

The tanshinone natural products have a variety of pharmacological properties including, anti-neoplastic activity. Ortho-quinone containing tanshinones were telomerase inhibitors through an oxidative mechanism mediated by production of hydrogen peroxide. To examine the importance of the ortho-quinone moiety, Soares et al. examined the telomerase inhibition by telomerase inhibitors and the simple ortho-quinone 9,10-phenanthrenequinone (PHQ). They found out that the ortho-quinone tanshinone Tan II-A and PHQ were equipotent inhibitors with $\mathrm{IC}_{50}=5.0 \mu \mathrm{M}$ (Fig. 22) [59].<smiles>Cc1coc2c1C(=O)C(=O)c1c-2ccc2c1CCCC2(C)C</smiles>

Tan II-A<smiles>O=C1C(=O)c2ccccc2-c2ccccc21</smiles>

PHQ
Fig. (22). Chemical structures of an ortho-quinone tanshinone (left) and 9,10-phenanthrenequinone (right).

Rubromycins are a family of structurally related compounds originally isolated from Actinomycetes that exhibit an attractive array for pharmacology (Fig. 23). Telomerase is a dimeric protein consisting of two reverse transcriptase motifs (TERT) with two RNA components (TR). $\beta$-rubromycin has revealed a competitive interaction with the telomerase substrate primer interacting both with the human telomerase RNA (TR) and the catalytic subunit (TERT), $\left(\mathrm{IC}_{50}=3.06\right.$ $\mu \mathrm{M})[60]$.

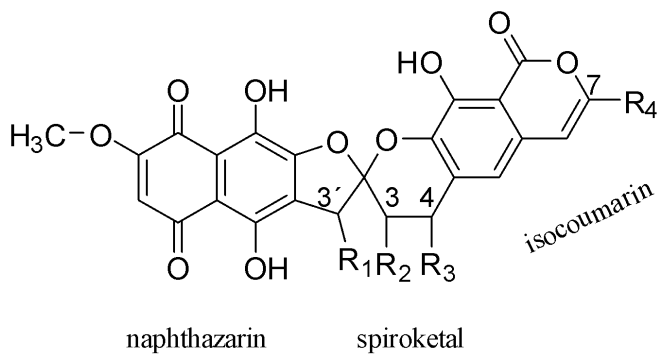

Fig. (23). General scaffold of rubromycins.

It was established that the high biological activity of rubromycin compounds significantly depends on the presence of the [5,6]-bisbenzannulated spiroketal moiety as a central structural motif. An elegant synthesis of $( \pm) \gamma-$ rubromycin was made by Michael Wilsdorf and HansUlrich Reissig, opening novel and challenging methods (Fig. 24) [61, 62].<smiles>COC(=O)c1cc2cc3c(c(O)c2c(=O)o1)O[C@]1(CC3)Cc2c(O)c3c(c(O)c2O1)C(=O)C=C(OC)C3=O</smiles>

Fig. (24). Chemical structure of $( \pm)-\gamma$-rubromycin.

\section{TOPOISOMERASE}

Another vital enzymes implicated in the replication, transcription, recombination or DNA repair processes are the topoisomerases $[63,64]$. These proteins direct and supervise the topological arrangement and orientation of DNA by relaxing torsion stress in supercoiled DNA sectors [65].

There are two major classes of topoisomerases, that share common characteristic, considering the nicking mechanism. Enzymes that cleave one strand of the DNA double strand are defined as topo I class; isoforms that cleave both strands are catalogued as topo II proteins $[66,67]$. Topo I produces the relaxation of DNA chain during replication by a single strand break in DNA. The single strand break is then relegated, thus restoring the DNA double strands, without any energy cofactor [68].

Today, in clinical and medical practice, mammalian DNA topoisomerases are considered prominent cellular targets of several anti-cancer drugs [69]. Perhaps, camptothecin analogues are the most topoisomerase inhibitors used; however, another kind of natural products are promising candidates.

\subsection{Lipids and Terpenes}

Mizushina et al. reported that some triterpenes are able to inhibit human topoisomerase II and some DNA polymerases. Remarkably, topo II and polymerase $\beta$ have a similar threedimensional triterpene-binding region, which is a hydrophobic pocket, able to specifically bind terpenoid compounds (Fig. 25).

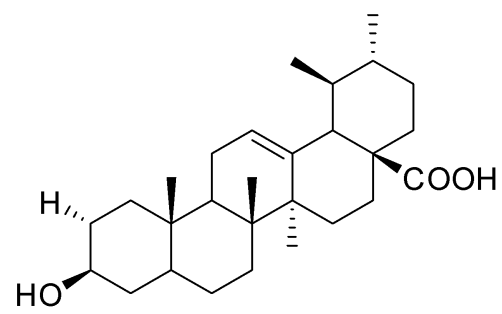

Fig. (25). Chemical triterpene scaffold from plant callus tissues of some Chinese medicinal plants.

Moreover, the hydroxyl moiety at "A ring" might generate a weaker inhibitory activity, but not the carboxyl group. This acidic group could have the required electronic density surface with the rest of terpene scaffold necessary for such inhibition. 
Moreover, Guo-Wei Wang et al. have isolated new Lanostane-type triterpenoids from Abies faxoniana (Fig. 26) [70].

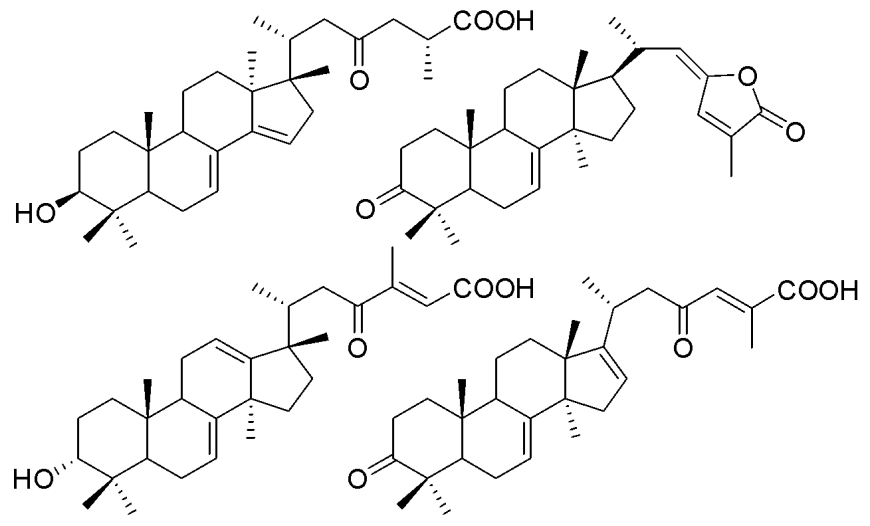

Fig. (26). Chemical structures of some lanostane-triterpenoids from Abies faxoniana.

Three of them have shown activity, and they share the carboxylic moiety at the end of the macrocyclic terpene structure. Interestingly, the fourth active compound shows a lactone moiety instead of the carboxylic residue, showing the best $\mathrm{IC}_{50}$ values. These chemically related groups share approximately the same van der Waals surface for each arrangement. However, the lactone group show a higher probability to insert inside of terpene topo hydrophobic pocket [71].

Another kind of derivatives bearing $\alpha, \beta$-unsaturated lactone are gibberellins. These potent topoisomerases I inhibitors belong to the tetracyclic diterpenes and show attractive cLogP values (Fig. 27) [72].

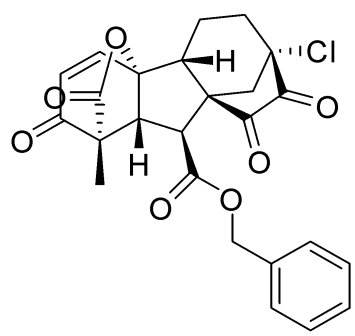

Fig. (27). Chemical structure of a gibberellin hydrophobic analogue.

\subsection{Alkaloids}

Fagaronine has been shown to interact inside of DNA, as well as with double stranded regions of ribonucleic acids, like tRNA (Fig. 28). As a cytotoxic agent, its activity seems to depend on the presence of the quaternary nitrogen because the desmethyl congener was inactive $[73,74]$.

Berberine salts analogues show a slightly buckled structure due to the partial saturation of the central ring. Berberine has been previously characterized as a DNA intercalating agent and as a cationic ligand, and electrostatic forces could play an important role in its interaction with DNA phosphates. Furthermore, electric linear dichroism experiments have shown that burasaine also interacts with DNA minor groove in an intercalation mode of binding (Fig. 29) [75].<smiles>COc1cc2c[n+](C)c3c4cc(OC)c(OC)cc4ccc3c2cc1OC</smiles>

Fig. (28). Chemical structure of fagaronine.<smiles></smiles>

Fig. (29). Chemical structure of burasaine.

Theoretical simulations using molecular docking studies have shown that these planar compounds bound with topoisomerase/DNA complex, mainly through $\pi-\pi$ stacking interactions [76].

Last year, Ashish Kumar et. al isolated a protoberberine group of isoquinoline alkaloids from Thalictrum foliolosum, including thalifendine and berberine. Surprisingly, they could find two new bisbenzylisoquinoline alkaloids. One of them displayed potent inhibitory activity against topoisomerase I in a concentration dependent manner (Fig. 30). Apparently, it did not stabilize enzyme/DNA covalent complex, acting as a class II inhibitor, which is a catalytic inhibitor of the enzyme [77].

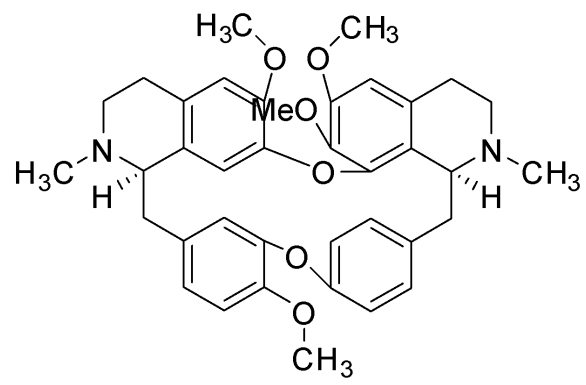

Fig. (30). Chemical structure of a bisbenzylisoquinoline alkaloid isolated from Thalictrum foliolosum.

Finally, $\beta$-carboline alkaloids represent a promising class of antitumoral drugs. Galianthe thalictroides (Rubiaceae), is a widespread shrub in Argentina, Brazil, Paraguay, and Uruguay, where it is popularly used to treat and prevent Cancer. A new cytotoxic $\beta$-carboline alkaloid from its roots, 1methyl-3-(2-hydroxypropan-2-yl)-2-(5-methoxy-9H- $\beta$ carbolin-1-yl) cyclopentanol, inhibited both topoisomerase I and topoisomerase II $\alpha$ better than etoposide, in a tested concentration of $1 \mu \mathrm{M}$ (Fig. 31) [78, 79].

\subsection{Flavonoids and Chalcones}

Flavonoids are widely spread in the plant kingdom and are common constituents of vegetables, fruits, and certain beverages. In 2010 López-Lázaro et al. evaluated the effects of four common dietary flavonoids (quercetin, apigenin, 
fisetin and myricetin) on topoisomerases at several concentrations using a cell-based assay (Fig. 32) [80, 81].

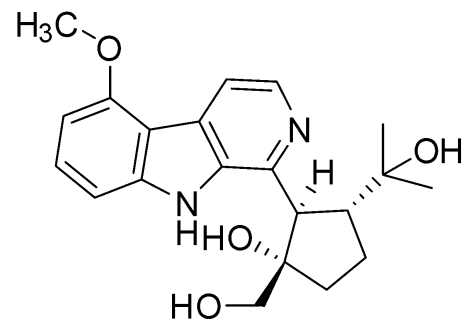

Fig. (31). Chemical structure of a $\beta$-carboline alkaloid isolated from Galianthe thalictroides.<smiles>O=C1C(O)=C(c2ccc(O)c(O)c2)Cc2cc(O)ccc21</smiles><smiles>O=C1C=C(c2ccc(O)cc2)Cc2cc(O)cc(O)c21</smiles>

Fig. (32). Chemical structures of some common dietary flavonoids.

They found that, in addition to the cancer preventive effects showed by some flavonoids, at higher concentrations (micromolar), these products may induce topoisomerasemediated DNA alterations that might have carcinogenic effects. This denotes the importance of finding more selective and active inhibitors at low concentrations.

Furthermore, quercetin diacylglycoside analogues have shown interesting activities against bacterial DNA gyrase and topoisomerase IV (Fig. 33). These compounds could be interesting for the study against human topoisomerases using a more rational design [82].

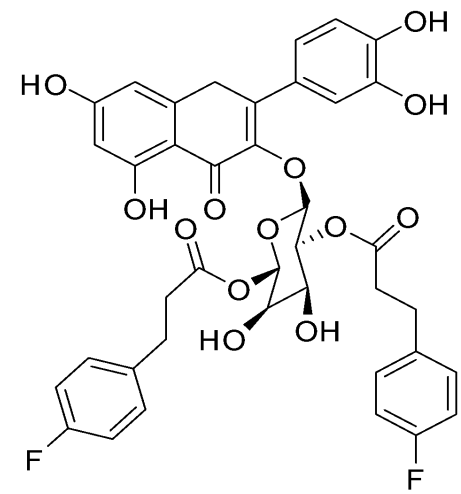

Fig. (33). Chemical scaffold of a quercetin diacylglycoside analogue.

The acyl glycoside present in flavonoids products seems to be an attractive moiety for activity. For example, a kaempherol glycoside derived from parts of two unique varieties of the Leguminosae, Vicia faba and Lotus edulis from Crete acted as catalytic inhibitor of wheat germ topoisomerase I and human topoisomerases I and II (Fig. 34) [83].<smiles>COC(=O)CC1CC2(O)CCC1C2Oc1c(-c2ccc(O)cc2)oc2cc(OC3OC4C(C)C(O)C(O)C(O3)C4O)cc(O)c2c1=O</smiles>

Fig. (34). Chemical structure of 2 , kaempferol 3-O-(5-O-acetyl- $\alpha$ $D$-apiofuranosyl)-7-O- $\alpha-L$-rhamnopyranoside.

Finally, using the chalcone scaffold as starting material, interesting families of inhibitors can be achieved by simple preparation methods; for example, by incorporating heteroaromatic cyclopropane rings (Fig. 35) [84, 85].<smiles>[X]c1ccccc1C=CC(=O)c1ccccc1OCC1CC1</smiles>

Fig. (35). Chemical scaffold of chalcone derivatives.

\section{CONCLUSION}

Several of the essential molecular mechanisms underlying malignant tumor biology remain still elusive and, thus, developing specific anticancer therapies remains a challenge. Medicinal plants and their natural products possess numerous bioactive principles which attack multiple targets, showing minor side effects, low potential to cause resistance, and remarkably low costs of production. The idea of DNA replication or DNA-repair interference as a potential tool approach to overcome intrinsic or acquired tumor resistance is gaining substantial attention. With respect to the inhibition of DNA repair pathways, it is desirable to avoid hurting normal cells.

Polymerases have a highly preserved structure, which means that their overall catalytic subunits motifs fluctuate very little from species to species. A preserved structure usually indicates that the protein has a crucial, irreplaceable function in the cell, the maintenance of which provides evolutionary advantages.

Telomerases are distinguished by having a particular catalytic activity from which RNA sequences can be employed as a template in a retro-transcription process. This feature could use reverse transcriptase inhibitors as potential telomerase inhibitors, thus increasing selectivity and specificity.

Topoisomerases are a special class of enzymes that do not require enzymatic cofactors or external energy to carry out their action. However, since its main function focuses on relieving DNA topology, and certain secondary structures, 
topoisomerases tend to have an affinity for the recognition of conjugated planar molecules, which can be found in nature.

Various products of natural origin and derivatives are useful pharmacological agents, but the search for new antitumoral and antiviral drugs remains still necessary.

\section{LIST OF ABBREVIATIONS}

$\begin{array}{ll}\text { BSA } & =\text { Bovine serum albumin } \\ \text { CD } & =\text { Circular dichroism } \\ \text { DNA } & =\text { Deoxyribonucleic acid } \\ \text { DNA Pol } & =\text { DNA polymerase } \\ \text { ESI-MS } & =\text { Electro spray ionization mass spectrometry } \\ \text { hTERT } & =\text { Human telomerase reverse transcriptase } \\ \text { PCR } & =\text { Polymerase chain reaction } \\ \text { PHQ } & =\text { Phenanthrenequinone } \\ \text { Pol } & =\text { Polymerase } \\ \text { RNA } & =\text { Ribonucleic acid } \\ \text { SAR } & =\text { Structure-activity relationship } \\ \text { Taq } & =\text { Thermus aquaticus } \\ t \text { RNA } & =\text { Transcriptional RNA }\end{array}$

\section{CONSENT FOR PUBLICATION}

Not applicable.

\section{CONFLICT OF INTEREST}

The authors declare no conflict of interest, financial or otherwise.

\section{ACKNOWLEDGEMENTS}

All Financial support from CONICET, UNSL (PROICO 02-2516 UNSL 2016) and ANPCyT is gratefully acknowledged. We thank Organic Area staff of the National University of San Luis for their help and also we appreciate revision of the manuscript by staff from the "Instituto de Lenguas, Universidad Nacional de San Luis".

\section{REFERENCES}

[1] Newman DJ, Cragg GM. Natural products as sources of new drugs over the last 25 years. J Nat Prod 2007; 70: 461-77.

[2] Cordell, GA. Changing strategies in natural products chemistry. Phytochemistry $1995 ; 40: 1585-112$.

[3] Shan C, Tan JE, Ou TM, Huang ZS. Natural products and their derivatives as G-quadruplex binding ligands. Sci China Chemistry 2013; 56: 1351-63.

[4] Gokbulut A, Kartal-Yandim M, Iskender G, Baran Y. Agents Targeting Bioactive Sphingolipids for the Treatment of Cancer. Curr Med Chem 2013; 20: 108-22.

[5] Morceau F, Chateauvieux S, Orsini M, Trécul A, Dicato M, Diederich M. Novel natural compounds and pharmaceuticals reprogram leukemia cell differentiation pathways. Biotech Adv 2015; 33: 785-97.

[6] da Costa JP, Carvalhais V, Amado F, et al. Anti-tumoral activity of human salivary peptides. Peptides 2015; 71: 170-8.

[7] Bosch-Barrera J, Menendez JA. Silibinin and STAT3: A natural way of targeting transcription factors for cancer therapy. Cancer Treat Rev 2015; 41: 540-6.

[8] Cragg, G.M.; Newman, D.J. Natural products: A continuing source of novel drug leads. Biochim. Biophys. Acta 2013; 1830: 3670-95.

[9] Pungitore CR. Natural Products, Synthetic and Non-Nucleoside Compounds as Inhibitors of Enzymes Related to DNA. Curr Enzyme Inhib 2014; 10: 13-38.

[10] Garro HA, Pungitore CR. Coumarins as Potential Inhibitors of DNA Polymerases and Reverse Transcriptases. Searching New Antiretroviral and Antitumoral Drugs. Curr Drug Discov Technol 2015; 12: 66-79.
Barakat K, Gajewski M, Tuszynski J. DNA polymerase beta $(\operatorname{pol} \beta)$ inhibitors: A comprehensive overview. Drug Discov Today 2012; 17: 913-20.

[12] Mentegari E, Kissova M, Bavagnoli L, Maga G, Crespan E. DNA Polymerases 1 and b: The Double-Edged Swords of DNA Repair. Genes 2016; 7: 1-17.

[13] Berdis AJ. DNA Polymerases as Therapeutic Targets. Biochemistry 2008; 47: 8253-60.

[14] Lange SS, Takata K, Wood RD. DNA polymerases and cancer. Nat Rev Cancer 2011; 11: 96-110.

[15] Hubscher U, Maga G, Spadari S. Eukaryotic DNA polymerases. Annu Rev Biochem 2002; 71: 133-63.

[16] Tseng, CK, Chen KJ, Lin CK, Hsu SH, Lee JC. An in vitro coupled transcription/translation reporter system for hepatitis C virus RNAdependent RNA polymerase. Anal Biochem 2011; 418: 50-7.

[17] Crespan E, Garbelli A, Amoroso A, Maga G. Exploiting the nucleotide substrate specificity of repair DNA polymerases to develop novel anticancer agents. Molecules 2011; 16: 7994-8019.

[18] Tuominen A. Defensive strategies in Geranium sylvaticum, Part 2: Roles of water-soluble tannins, flavonoids and phenolic acids against natural enemies. Phytochemistry 2013; 95: 408-20.

[19] Seleem D, Pardi V, Mendonça-Murata R. Review of flavonoids: A diverse group of natural compounds with anti-Candida albicans activity in vitro. Arch Oral Biol 2017; 76: 76-83.

[20] Sawadjoon S, Kittakoop P, Kirtikara K, Vichai V, Tanticharoen M, Thebtaranonth Y. Myristinin is a bioflavonoid isolated from Myristica cinnamomea. J Org Chem 2002; 67: 5470-5.

[21] Maloney DJ, Deng JZ, Starck SR, Gao Z, Hecht SM. (+)Myristinin A, a Naturally Occurring DNA Polymerase â Inhibitor and Potent DNA-Damaging Agent. JACS Comm 2005; 127: 41401.

[22] Merlo S, Basile L, Giuffrida ML, Sortino MA, Guccione S, Copani A. Identification of 5-Methoxyflavone as a Novel DNA Polymerase-Beta Inhibitor and Neuroprotective Agent against BetaAmyloid Toxicity. J Nat Prod 2015; 78: 2704-11.

[23] Gerhauser C, Alt A, Heiss E, Gamal-Eldeen A, Klimo K, Knauft J. Cancer chemopreventive activity of xanthohumol, a natural product derived from hop. Mol. Cancer Ther 2002; 1: 959-69.

[24] Coulerie P, Nour M, Maciuk A, et al. Structure-Activity Relationship Study of Biflavonoids on the Dengue Virus Polymerase DENV-NS5 RdRp. Planta Med 2013; 79: 1313-8.

[25] Reta G, Chiaramello A, García C, et al. Derivatives of grindelic acid: From a non-active natural diterpene to synthetic antitumor derivatives. Eur J Med Chem 2013; 67: 28-38.

[26] Manayi A, Nabavi SM, Daglia M, Jafari S. Natural terpenoids as a promising source for modulation of GABAergic system and treatment of neurological diseases. Pharmacol Rep 2016; 68: 671-9.

[27] Dvora H, Koffas MAG. In: Microbial production of flavonoids and terpenoids. Microbial Production of Food Ingredients, Enzymes and Nutraceuticals. Ed.; Woodhead Publishing Series in Food Science, Technology and Nutrition 2013; Vol. 10, pp: 234-61.

[28] Yaoita Y, Kikuchi M, Machida K. In: Studies in Natural Products Chemistry; Atta-ur-Rahman. Ed.; Elsevier Science B.V: Amsterdam 2015; Vol. 44, pp: 1-32.

[29] Houghton P, Mensah A, Iessa N, Hong L. Terpenoids in Buddleja: relevance to chemosystematics, chemical ecology and biological activity. Phytochemistry, 2003; 64: 385-93.

[30] Mizushina Y, Tanaka N, Yagi H, et al. Fatty acids selectively inhibit eukaryotic DNA polymerase activities in vitro. Biochim Biophys Acta 1996; 1308: 256-62.

[31] Mizushina Y, Miyazaki S, Ohta K, Hirota M, Sakaguchi K. Novel anti-infammatory compounds from Myrsine seguinii, terpenobenzoic acids, are inhibitors of mammalian DNA polymerases. Biochim Biophys Acta 2000; 1475: 1-4.

[32] Deng JZ, Starck SR, Sun DA, Sabat M, Hecht SM. A new 7,8euphadien-type triterpenoid from Brackenridgea nitida and Bleasdalea bleasdalei that inhibits DNA Polymerase. J Nat Prod 2000; 63: $1356-60$

[33] Gao Z, Maloney DJ, Dedkova LM, Hecht SM. Inhibitors of DNA polymerase $\beta$ : activity and mechanism. Bioorg Med Chem 2008; 16: 4331-40.

[34] Bartnik PC, Delgoda R, Facey M. In: Glycosides Pharmacognosy; Ed.; Academic Press: Boston 2017, pp: 101-61.

[35] Gerwig G, Poele E, Dijkhuizen L, Kamerling J. Stevia Glycosides: Chemical and Enzymatic Modifications of Their Carbohydrate 
Moieties to Improve the Sweet-Tasting Quality. Adv Carbohydr Chem Biochem 2016; 73: 1-72.

[36] Martin OA, Garro HA, Kurina-Sanz M.B, Pungitore CR, Tonn CE. In silico study of the inhibition of DNA polymerase by a novel catalpol derivative. J Mol Model 2011; 17: 2717-23.

[37] Pungitore CR, Juri-Ayub M, Borkowsky E, Tonn CE, Ciuffo GM. Inhibition of Taq DNA polymerase by catalpol. Cell Mol Biol 2004; 50: 767-72.

[38] Pungitore CR, Leon L, García C, Martín V, Tonn CE, Padrón JM. Novel antiproliferative analogs of the Taq DNA polymerase inhibitor catalpol. Bioorg Med Chem Lett 2007; 17: 1332-5.

[39] Garro HA, García C, Martín V, Tonn CE, Pungitore CR. A new iridoid, verbascoside and derivatives with inhibitory activity against Taq DNA polymerase. Bioorg Med Chem Lett 2015; 25: 914-8.

[40] Mizushina Y, Kamisuki S, Kasai N, et al. Petasiphenol: A DNA polymerase $l$ inhibitor. Biochem 2002; 41: 14463-71.

[41] Islam M, Jackson P, Rahman K, Thurston D. Recent advances in targeting the telomeric G-quadruplex DNA sequence with small molecules as a strategy for anticancer therapies. Future Med Chem 2016; 10: 4155-86.

[42] Aissaa K, Ebbenc J, Kadleca A, Beyera A. Friend or foe? Telomerase as a pharmacological target in cancer and cardiovascular disease. Pharmacol Res 2016; 11: 422-33.

[43] Dominick P, Keppler B, Legassie J, Moon I, Jarstfer M. Nucleic acid-binding ligands identify new mechanisms to inhibit telomerase. Bioorg Med Chem Lett 2004, 14, 3467-71.

[44] Raymond E, Sun D, Chen SF, Windle B, Von Hoff D. Agents that target telomerase and telomeres. Curr Opin Biotechnol 1996; 7 : $583-91$.

[45] Arora A, Kumar N, Agarwal T, Maiti S. Human telomeric Gquadruplex: targeting with small Molecules. FEBS J 2010; 277: 1345-61.

[46] Zhou JL, Lu YJ, Ou TM, et al. Synthesis and evaluation of quindoline derivatives as G-quadruplex inducing and stabilizing ligands and potential inhibitors of telomerase. J Med Chem 2005; 48: 7315-21.

[47] Zhou JM, Zhu XF, Lu YJ, et al. Senescence and telomere shortening induced by novel potent G-quadruplex interactive agents, quindoline derivatives, in human cancer cell lines. Oncogene 2006; 25 : 503-11.

[48] Franceschin M, Rossetti L, D'Ambrosio A, et al. Natural and synthetic G-quadruplex interactive berberine derivatives. Bioorg Med Chem Lett 2006; 16: 1707-11.

[49] Ma Y, Ou TM, Hou JQ. N-Substituted berberine derivatives: Stabilization of G-quadruplex DNA and down-regulation of oncogene cmyc. Bioorg Med Chem Lett, 2008; 16: 7582-619.

[50] Ghosh S, Dasgupta D. Quadruplex forming promoter region of cmyc oncogene as a potential target for a telomerase inhibitory plant alkaloid, chelerythrine. Biochem Biophys Res Commun 2015; 459: 75-80.

[51] Li H, Zhanga S, Zhou J, Yang X. Specific binding of human telomeric G-quadruplex by homobarringtonie: An alkaloid from traditional Chinese medicine. Int J Mass Spectrom 2015; 379: 157-64

[52] Kadri T, Rouissi T, Brar SK, Cledon M, Sarma S, Verma M. Biodegradation of polycyclic aromatic hydrocarbons (PAHs) by fungal enzymes: A review. J Environ Sci 2017; 51: 52-74.

[53] Wei C, Wang L, Jia G, Zhou J, Han G, Li C. The binding mode of porphyrins with cation side arms to $\left(\mathrm{TG}_{4} \mathrm{~T}\right) 4 \mathrm{G}$-quadruplex: Spectroscopic evidence. Bioph Chem 2009; 143: 79-84.

[54] Franceschin M, Pascucci E, Alvino A, et al. New highly hydrosoluble and not self-aggregated perylene derivatives with three and four polar side-chains as G-quadruplex telomere targeting agents and telomerase inhibitors. Bioorg Med Chem Lett, 2007; 17: 251522

[55] Franceschin M, Alvino A, Casagrande V, et al. Specific interactions with intra- and intermolecular G-quadruplex DNA structures by hydrosoluble coronene derivatives: A new class of telomerase inhibitors. Bioorg Med Chem Lett, 2007; 15: 1848-58.

[56] Saify ZS, Mushtaq N, Noor F, Takween S, Arif M. Role of quinone moiety as antitumor agents: a review. Pak J Pharm Sci, 1999; 12: 21-31.

[57] Tang WJ, Wang J, Tong X, Shi JB, Liu XH, Li J. Design and synthesis of celastrol derivatives as anticancer agents. Eur $\mathrm{J}$ Med Chem 2015; 95: 166-173.
[58] Cai XH, Jin J, Huiyuan HM. Advances in structural modifications of celastrol. ARKIVOC 2016; (i): 172-182.

[59] Soares J, Keppler B, Wanga X, Lee KH, Jarstfer M. ortho-Quinone tanshinones directly inhibit telomerase through an oxidative mechanism mediated by hydrogen peroxide. Bioorg Med Chem Lett 2011; 21: 7474-7478.

[60] Atkinsonab D, Brimble M. Isolation, biological activity, biosynthesis and synthetic studies towards the rubromycin family of natural products. Nat Prod Rep 2015; 32: 811-40.

[61] Wilsdorf M, Reissig HU. A Convergent Total Synthesis of the Telomerase Inhibitor $( \pm)$ - $g$-Rubromycin. Angew Chem Int Ed 2014; 53: 1-6.

[62] Ueno T, Takahashi H, Oda M, et al. Inhibition of human telomerase by rubromycins: implication of spiroketal system of the compounds as an active moiety. Biochemistry, 2000; 39: 5995-6002.

[63] Pommier Y. Topoisomerase I inhibitors: camptothecins and beyond. Nat Rev Cancer 2006; 6: 789-802.

[64] Baranello L, Kouzine F, Levens D. DNA topoisomerases: beyond the standard role. Transcription 2013; 4: 232-7.

[65] Cheng B, Annamalai T, Sorokin E, Abrenica M, Aedo S, Tse-Dihn YC. Asp-To-Asn substitution at the first position of the DXD toprim motif of recombinant bacterial topoisomerase $\mathrm{I}$ is extremely lethal to E. coli. J Mol Biol 2009; 385: 558-67.

[66] Ireton G, Stewart L, Parker L, Champoux J. Expression of human topoisomerase I with a partial deletion of the linker region yields monomeric and dimeric enzymes that respond differently to camptothecin. J Biol Chem 2000; 275: 25820-30.

[67] Forterre P, Gribaldo S, Gadelle D, Serre MC. Origin and evolution of DNA topoisomerases. Biochimie 2007; 89: 427-46.

[68] Teicher B. Next generation topoisomerase I inhibitors: Rationale and biomarker strategies. Biochem Pharmacol 2008; 75: 1262-71

[69] Reuveni D, Halperin D, Shalit I, Priel E, Fabian I. Quinolones as enhancers of camptothecin-induced cytotoxic and antitopoisomerase I effects. Biochem. Pharmacol 2008; 75: 1272-81.

[70] Mizushina Y, Ikuta A, Endoh K. Inhibition of DNA polymerases and DNA topoisomerase II by triterpenes produced by plant callus. Biochem Biophys Res Commun 2003; 305: 365-73.

[71] Wang GW, Lv C, Yuan X, et al. Lanostane-type triterpenoids from Abies faxoniana and their DNA topoisomerase inhibitory activities. Phytochemistry 2015; 116: 221-9.

[72] Chen J, Sun Z, Zhang Y, et al. Synthesis of gibberellin derivatives with anti-tumor bioactivities. Bioorg Med Chem Lett 2009; 19: 5496-9.

[73] Pezzuto JM, Antosiak SK, Messmer WM, Slaytor B, Honig GR. Interaction of the antileukemic alkaloid, 2-hydroxy-3,8,9trimethoxy-5-methylbenzo-[c]-phenanthridine (fagaronine) with nucleic acids. Chem Biol Interact 1983; 43: 323-39.

[74] Larsen AK, Grondard L, Couprie J, et al. The antileukemic alkaloid fagaronine is an inhibitor of DNA topoisomerases I and II. Biochem Pharmacol 1993; 46: 1403-12.

[75] Kluza J, Baldeyrou B, Colson P, et al. Cytotoxicity and DNA binding properties of the plant alkaloid burasaine. Eur J Pharm Sci 2003; 20: 383-91.

[76] Basili S, Basso G, Faccio A, et al. Diazoniapolycyclic ions inhibit the activity of topoisomerase I and the growth of certain tumor cell lines. ChemMedChem 2008; 3: 1671-6.

[77] Kumar A, Chowdhury SR, Sarkar T, Chakrabarti T, Majumder HK Jha T, Mukhopadhyay S. A new bisbenzylisoquinoline alkaloid isolated from Thalictrum foliolosum, as a potent inhibitor of DNA topoisomerase IB of Leishmania donovani. Fitoterapia 2016; 109: 25-30.

[78] Figueiredo PO, Garcez FR, Matos MFC, et al. A New Cytotoxic $\beta$ Carboline Alkaloid from Galianthe thalictroides. Planta Med 2011; 77: 1852-4.

[79] Figueiredo PO, Perdomo RT, Garcez FR, Matos MFC, de Carvalho JE, Garcez WS. Further constituents of Galianthe thalictroides (Rubiaceae) and inhibition of DNA topoisomerases I and IIa by its cytotoxic $b$-carboline alkaloids. Bioorg Med Chem Lett 2014; 24: 1358-61.

[80] Li Y, Fang H, Xu W. Recent advance in the research of flavonoids as anticancer agents. Mini Rev Med Chem 2007; 7: 663-78.

[81] López-Lázaroa M, Willmorea E, Austina C. The dietary flavonoids myricetin and fisetin act as dual inhibitors of DNA topoisomerases I and II in cells. Mutat Res 2010; 696: 41-7. 
[82] Hossion A, Zamami Y, Kandahary R, et al. Quercetin Diacylglycoside Analogues Showing Dual Inhibition of DNA. J Med Chem 2011; 54: 3686-703.

[83] Tselepi M, Papachristou E, Emmanouilidi A, et al. Catalytic inhibition of eukaryotic topoisomerases I and II by flavonol glycosides extracted from Vicia faba and Lotus edulis. J Nat Prod 2011; 74: $2362-70$.
[84] Jeon KH, Yu HB, Kwak SY, Kwon Y, Na Y. Synthesis and topoisomerases inhibitory activity of heteroaromatic chalcones. Bioorg Med Chem 2016; 24: 5921-8.

[85] Fernández-García JM, Garro HA, Fernández-García L, et al. Goldcatalyzed cycloisomerizations of functionalyzed cyclopropyl alkynes: the cases of carboxamides and alcohols. Adv Synth Catal 2017; 359: 3035- 51 